\title{
DNA Vaccine and its Importance in Veterinary
}

\author{
Mansour Ebrahimi* \\ Department of Pathobiology, Shahid Chamran University of Ahvaz, Iran
}

Submission: April 12, 2019; Published: May 09, 2019

*Corresponding author: Mansour Ebrahimi, Department of Pathobiology, Faculty of Veterinary Medicine, Shahid Chamran University of Ahvaz, Ahvaz, Iran

Abstract

This mini review briefly dealt with importance of DNA vaccine in veterinary and presented some information about this kind of vaccine. Since there are problems with traditional vaccines, it is necessary to use new technologies to design high-efficient DNA vaccines against animal diseases.

Keywords: DNA vaccine; Veterinary field; Immune response

\section{Introduction}

A DNA vaccine is described as an antigen encoding plasmid that, when introduced into the body, results in in vivo expression of the antigen, with a subsequent antigen-specific immune response [1]. DNA vaccine consists of a recombinant foreign gene cloned into a double-stranded, closed-circular bacterial plasmid vector. The plasmid generally contains an origin of replication (for amplification in bacteria), a bacterial antibiotic resistance gene (to allow for selection), the gene(s) of interest under the transcriptional control of a (viral) promoter and enhancer sequences (to obtain strong expression in mammalian cells) followed by an mRNA polyadenylation sequence [2]. DNA vaccines are cost-effective; they can be designed, manufactured and stored with relative ease [3]. They are non-infectious and do not promote inflammation at the site of immunization; important factors in vaccinations for food animals. DNA vaccines can be used as marker vaccines to differentiate vaccinated and infection-exposed animals in eradication programs. DNA vaccines stimulate both humoral and cellular immunity, and thus promote development of a balanced immune response [4].

Nowadays, there have been immense advances in the field of DNA vaccines. This has been a result of new and better vectors, different types of delivery methods and devices, addition of immunologic adjuvants, and harnessing (or decreasing the activation of) the innate system, which is activated by the plasmid DNA itself, and can be further activated by encoded proteins [5]. The application of DNA immunization as a new generation vaccine has been well studied since its invention, and a variety of such vaccines have undergone clinical trials, in veterinary practice [6]. Regarding veterinary practice, numerous trials of DNA vaccines have been carried out against various animal diseases such as foot and mouth disease (FMD) and herpes virus infection in cattle, Aujeszky's disease and classical swine fever in swine, rabies and canine distemper in canines, and avian influenza, infectious bronchitis, infectious bursal disease and coccidiosis in birds [7$11]$.

\section{Discussion}

Vaccines for livestock are essential for herd health, economic survival of farmers, and the maintenance of trade of meat and other animal products between countries [12]. Vaccination with DNA is one of the most promising novel immunization techniques against pathogens, for which conventional vaccination regimens have been less effective. Given the relative inefficacy of commercial vaccines and the contraindications of some of these, there is much room for improvement DNA vaccine studies [13]. Given the promising results of DNA vaccines against pathogens, it should be developed for diseases where traditional vaccination is not very effective or only treats clinical signs and does not prevent disease (such as FMD) [14]. Also, DNA vaccine should also be looked into as an option if there is concern about tradiᄀtional vaccination causing an outbreak in a herd or causing adverse effects on the animal [12].

\section{Conclusion}

Ultimately, the factors that will make a DNA vaccine attrac $\neg$ tive for a certain disease will include its reduced cost, its ease of transport and administration, its ability to act in the face of maternal antibodies, the ability to differentiate diseased animals from vaccinated animals, and the reduced likelihood of the 
vac $\neg$ cine to cause an outbreak. Not all DNA vaccines induce a high enough degree of protection in larger animals and humans. The improvement of DNA vaccine immune potency must be achieved, through prom 7 ising technologies as improved formulations or simple electropo $\neg$ ration, or alternate vaccination strategies should be considered, such as prime-boost approaches, cytokine gene adjuvants or other adjuvant formulations.

\section{Conflict of Interest}

The author declares that there is no conflict of interests.

\section{References}

1. Gurunathan S, Klinman DM, Seder RA (2000) DNA vaccines: immunology, application, and optimization. Annu Rev Immunol 18: 927-974.

2. Flotte TR and Lu S (2018) DNA Vaccination in 2018: An Update. Hum Gene Ther 29(9): 963-965

3. Kurath G (2008) Biotechnology and DNA vaccines for aquatic animals. Rev Sci Tech 27(1): 175-196.

4. Laddy DJ, Yan J, Corbitt N, Kobasa D, Kobinger GP, et al. (2007) Immunogenicity of novel consensus-based DNA vaccines against avian influenza. Vaccine 25(16): 2984-2989.

5. Abdo Hasson SSA, Al-Busaidi1JKZ, Sallam TA (2015) The past, current and future trends in DNA vaccine immunisations. Asian Pac J Trop Biomed 5(5): 344-353.

This work is licensed under Creative Commons Attribution 4.0 License

DOI: $10.19080 / J D V S .2019 .11 .555819$
6. Dhama K, Mahendran M, Gupta PK, Rai A (2008) DNA vaccines and their applications in veterinary practice: current perspectives. Vet Res Commun 32(5): 341-356.

7. Oshop GL, Elankumaran S, Heckert RA (2002) DNA vaccination in avian. Vet Immunol Immunopathol 89: 1-12.

8. Dunham SP (2002) The application of nucleic acid vaccines in veterinary medicine. Res Vet Sci 73: 9-16.

9. Ding X, Lillehoj HS, Dalloul RA, Min W, Sato T, et al. (2005) In ovo vaccination with the Eimeria tenella EtMIC2 gene induces protective immunity against coccidiosis. Vaccine 23: 3733-3740.

10. Gupta PK, Sharma S, Walunj SS, Patil AA, Rai A, et al. (2006) A DNA vaccine that encodes rabies virus glycoprotein lacking transmembrane domain enhances antibody response but not protection. Acta Virol 50: 87-92.

11. Patial S, Chaturvedi VK, Rai A, Saini M, Chandra R, et al. (2007) Virus neutralizing antibody response in mice and dogs with a bicistronic DNA vaccine encoding rabies virus glycoprotein and canine parvovirus VP2. Vaccine 25: 4020-4028.

12. Redding L, Werner DB (2009) DNA vaccines in veterinary use. Expert Rev Vaccines 8(9): 1251-1276.

13. Wahren B, Liu MA (2014) DNA Vaccines: Recent Developments and the Future. Vaccines (Basel) 2(4): 785-796

14. Shao HJ, Chen L, Su YB (2005) DNA Fragment Encoding Human IL-1及 163-171 Peptide Enhances the Immune Responses Elicited in Mice by DNA Vaccine against Foot-and-Mouth Disease. Vet Res Com 29: 35-46.

Your next submission with Juniper Publishers
will reach you the below assets
- Quality Editorial service
- Swift Peer Review
- Reprints availability
- E-prints Service
- Manuscript Podcast for convenient understanding
- Global attainment for your research
- Manuscript accessibility in different formats
( Pdf, E-pub, Full Text, Audio)
- Unceasing customer service
Track the below URL for one-step submission
https://juniperpublishers.com/online-submission.php

